\title{
Malaria and Quinine Resistance: A Medical and Scientific Issue between Brazil and Germany (1907-19)
}

\author{
ANDRÉ FELIPE CÂNDIDO DA SILVA ${ }^{1 *}$ and JAIME LARRY BENCHIMOL ${ }^{2 *}$ \\ ${ }^{1}$ Department of History, Faculty of Philosophy, Languages and Literature and Human Sciences \\ (FFLCH), University of São Paulo, Av. Professor Luciano Gualberto, 315, Cicade Universitária, \\ CEP: 05508.900, Sao Paulo - SP, Brazil \\ ${ }^{2}$ Casa de Oswaldo Cruz - FIOCRUZ, Av. Brasil, 4036/403, CEP 21040.361, \\ Rio de Janeiro - RJ, Brazil
}

\begin{abstract}
This article addresses the discussion about quinineresistant malaria plasmodium in the early decades of the twentieth century. Observed by Arthur Neiva in Rio de Janeiro in 1907, the biological and social resistance of malaria sufferers to preventive and curative treatment with quinine was corroborated three years later by Oswaldo Cruz during the construction of the Madeira-Mamoré Railway in the Brazilian Amazon. Likewise in 1910, ailing German workers were transferred from Brazil to Hamburg's Institute for Maritime and Tropical Diseases, where quinine resistance was confirmed by Bernard Nocht and Heinrich Werner. When the First World War saw failures in treating and preventing malaria with quinine along with violent outbreaks of the disease on the Turkish and Balkan fronts, resistance to this alkaloid became the topic of the day within the field of experimental medicine in Germany. New attempts were made to account for the resistance, especially by the physician Ernst Rodenwaldt, who explored the topic by applying modern theories on heredity. The present article offers a preliminary survey and analysis of pronouncements about quinine resistance, shedding new light on the circulation of knowledge in the field of tropical medicine.
\end{abstract}

Keywords: Malaria, Quinine Resistance, History of Tropical Medicine, Arthur Neiva, Ernest Rodenwaldt

In 1909 a ship docked in Hamburg with German workers returning from the Amazon, where the Madeira-Marmoré railway was being built. Most of them had malaria, a disease so prevalent there that the works had become known as the 'devil's railway'. ${ }^{1}$ In 1909, half of the 700 or so Europeans involved in building it had lost their lives after spending just

\footnotetext{
* Email addresses for correspondence: andrefelipe@usp.br, jben@cdc.fiocruz.br Research supported by FAPESP and FAPERJ. We thank Miriam Junghans for the translation of German texts.

${ }^{1}$ Manoel Rodrigues Ferreira, A Ferrovia do Diabo (São Paulo: Melhoramentos, 2005).
} 
six months there. Those who made it back to Hamburg were in a deplorable state. ${ }^{2}$ Sixtythree of the recent arrivals were admitted to the Sailors' Hospital (Seemannskrankenhaus), attached to the Institute for Maritime and Tropical Diseases of Hamburg (Institut für Schiffs- und Tropenkrankheiten). ${ }^{3}$ Its director, Bernhard Nocht, and a military doctor, Heinrich Werner, were surprised by the unusual form of the disease and the fact that it did not respond as expected to quinine. Nocht and Werner had already learnt of the plasmodium's resistance to the alkaloid in the Brazilian hinterlands from an article by Miguel Couto published in 1908 in Bulletin de la Societé de Pathologie Exotique, and as well as from a work by Arthur Neiva which would be published in 1910 in Memórias do Instituto Oswaldo Cruz. ${ }^{4}$ Neiva had observed the plasmodium's resistance to quinine in a campaign against malaria in the lowlands in Rio de Janeiro state three years earlier, when the waters of the Xerém river were channelled to supply the city of Rio de Janeiro, then the Brazilian capital. ${ }^{5}$

This study investigates the statements made by Brazilian and German doctors about the malaria plasmodium's resistance to quinine. Neiva's observations and hypotheses were appropriated, reviewed and criticised by the Germans, who faced similar problems during the First World War. Despite the disagreements and controversies, it was recognised on both sides of the Atlantic that this issue, which was jeopardising the work of anti-malaria campaigns, had to be addressed. As we accompany this debate, it becomes clear how knowledge was circulated amongst those involved in tropical medicine and how Brazilian researchers were engaged in this dynamic. Not only did they adapt the prescriptions published in domestic and foreign medical publications to the local circumstances they encountered, but they also opened up new research fronts thanks to their observations, made mostly in malaria-infested regions of inland Brazil, where rail, hydroelectric, hydraulic and farming projects were underway. In Germany, the study of quinine resistance was spearheaded by the Hamburg Institute of Tropical Diseases and one of its former students. The efforts made by Bernhard Nocht, Heinrich Werner, Peter Mühlens and other researchers to understand the phenomenon reveals just how important malaria prevention was to the research and educational agenda of the Tropeninstitut. It was the most widespread disease amongst the patients at the Sailors' Hospital and posed the biggest challenge for the doctors working in German overseas possessions. As for Ernst Rodenwaldt, better known for his work as a racial hygiene and eugenics theoretician, researching quinine resistance gave him a chance to look into aspects of genetics and heredity, which he applied to the behaviour of the malaria parasite. From protozoa he

\footnotetext{
2 Bernhard Nocht and Heinrich Werner, 'Beobachtungen über relative Chininresistenz bei Malaria aus Brasilien', Deutsche Medizinische Wochenschrift, 34 (1910), 1557-69.

3 The Institute of Maritime and Tropical Diseases of Hamburg was founded in 1900 with the aim of investigating the main diseases found in hot regions of the world and prevent them from being introduced to German territory. They inspected the vessels that docked at the port of Hamburg and treated the sick who arrived there from abroad. The 'Tropeninstitut' also trained the doctors who would be posted to German colonies. For more on the institute, see Erich Mannweiler, Geschichte des Instituts für Schiffs-und Tropenkrankheiten in Hamburg, 1900-1945 (Keltern-Weiler: Goecke und Evers, 1998) and Stefan Wulf, Das Hamburger Tropeninstitut 1919 bis 1945: Auswärtige Kulturpolitik und Kolonialrevisionismus nach Versailles (Berlin and Hamburg: Reimer, 1994).

${ }^{4}$ Miguel Couto, 'Les injections endo-veineuses du bleu de méthylène dans le paludisme', Bulletin de la Société de Pathologie exotique, 1, 5, (13 May 1908), 292-5; Arthur Neiva, 'Formação de raça do hematozoario do impaludismo rezistente à quinina', Memórias do Instituto Oswaldo Cruz, 2, 1 (1910), 131-40.

5 Jaime Larry Benchimol and André Felipe Cândido da Silva, 'Railroads, Disease, and Tropical Medicine in Brazil under the First Republic', História, Ciências, Saúde - Manguinhos, 15, 3 (2008), 719-62. Available at http://www.scielo.br/pdf/hcsm/v15n3/en_09.pdf.
} 
passed to humans, devising and publicising his conceptions and thereby lending scientific legitimacy to the policies developed by the Nazi regime and their dramatic consequences.

\section{Malaria Campaigns in Brazil and Resistance to Quinine}

Between 1903 and 1906, Oswaldo Cruz, Director-General of Public Health, had devoted his energies to improving sanitary conditions in Rio de Janeiro, a government priority under the administration of Francisco de Paula Rodrigues Alves (1902-6). If yellow fever put a damper on the country's business prospects and image abroad, malaria made it virtually impossible to build the infrastructure needed to connect the country's inland regions to its ports. To control it, researchers new to the ranks of the Instituto Soroterapico Federal (renamed the Instituto Oswaldo Cruz in 1908 and also known as the Instituto de Manguinhos $)^{6}$ pulled together the knowledge that had been amassed on the disease, creatively adapting it to the realities they encountered in the field. ${ }^{7}$

Carlos Chagas, a young doctor recently admitted to the institute, had been dispatched in 1905 to fight malaria in Itatinga, in São Paulo state, where a dam was under construction to provide power for the port in Santos, then the largest exporter of coffee. Chagas identified which species of Anopheles were present in the region, describing some that were new to science. He chose to administer quinine preventively, drain and landfill wetlands, and provide collective protective measures for the workers in the form of screens in their lodgings, while keeping the chronically ill in isolation and providing treatment for acute cases. $^{8}$

In early 1907, Chagas and another researcher recently admitted to the institute, Arthur Neiva, were sent to the vast swampy plains near Rio de Janeiro, known as Baixada Fluminense. Chagas stayed there just three months before being sent to to fight malaria in Minas Gerais, where the Central do Brasil railway was being extended. There, he came across a new human trypanosomiasis, which was later named after him: Chagas Disease. ${ }^{9}$

When they reached the Baixada Fluminense plains, they found almost all the workers suffering from malaria and a few work sites already shut down. Spanish and Portuguese immigrants were taken straight from the port to the work site by rail to prevent alarming news of the state of affairs from reaching them and scaring them off. Much of the land where pipes were being laid was swampy, and the workers were often up to their waists in water. By 1908, there were close on four thousand workers there. Many brought their

\footnotetext{
${ }^{6}$ In order to lend legitimacy to the transformation of the laboratory created in 1899 to produce serums and vaccines against bubonic plague into an institute of experimental medicine where other biological products were made, microbiology and tropical medicine were taught, and research was undertaken in these areas, Oswaldo Cruz found different ways to associate the knowledge produced there with its different clients and the demands of the early republican years in Brazil and the international scientific community as a whole. For more on this, see: Nancy Stepan, Gênese e evolução da ciência brasileira (Rio de Janeiro: Artenova, 1976); Jaime Larry Benchimol, Manguinhos do sonho à vida: A ciência na Belle Époque (Rio de Janeiro: Fiocruz/ Casa de Oswaldo Cruz, 1990); Jaime Larry Benchimol, 'Pasteur, la santé publique et la recherche biomédicale au Brésil' in Nisia Trindade Lima and Marie-Hélene Marchand (eds), Louis Pasteur e Oswaldo Cruz (Rio de Janeiro: Fiocruz/Banco BNP Paribas Brasil S.A, 2005), 215-73.

${ }^{7}$ Benchimol and Silva, op. cit. (note 5), 731-3.

${ }^{8}$ Carlos Chagas, Prophylaxia do impaludismo (Rio de Janeiro: Typ. Besnard Frères; 1906/7), Carlos Chagas, 'Prophylaxia do impaludismo: Nota previa sobre uma causa de erro nos exames de sangue para a pesquiza do hematozoario de Laveran', Revista Medica de São Paulo, 11, 19 (1908), 391-9.

${ }^{9}$ Simone Petraglia Kropf, Doença de Chagas, doença do Brasil: Ciência, saúde e nação 1909-1962 (Rio de Janeiro: Fiocruz, 2009).
} 
families to the region, which also attracted travelling salesmen, merchants and other migrants. ${ }^{10}$

A wooden hospital protected by mosquito screens was built at the end of the railway. The General Inspectorate of Public Works was responsible for all water treatments; insect larvae were killed by the spraying of oil, water tanks in houses were covered, and larvaeating fish were introduced. As in railway construction projects and scientific and military expeditions across malaria zones, quinine was the mainstay of the campaign, being used for both treatment and prevention. ${ }^{11}$

The workers soon protested against having to take quinine for prophylactic purposes, prompting Neiva to impose a strict, compulsory system: either the workers took the alkaloid or they would lose their jobs. He even had assistants, known as 'quininisers', who had to make sure they had actually swallowed the capsules, rather than palming them or hiding them under their tongue. ${ }^{12}$

The daily dose of $30 \mathrm{cg}$ recommended in the manuals by Patrick Manson, Botto Scheube and Carl Mense had already proved insufficient in Itatinga. ${ }^{13}$ From February to August 1907, the workers at Xerém started to be given 50cg of quinine hydrochloride, produced by Merck, every three days, which yielded promising results. However, from late August and into September, Neiva started to see a relatively large number of first-time infections amongst the workers who had taken the higher dose of quinine preventively. He first put it down to higher individual susceptibility, since the cases then being recorded were of workers who had failed to follow protocol regarding the taking of quinine. The morbidity rate was just $0.59 \%$, which seemed to suggest they were on the right track, even though the protocol could not be applied to workers' families and other migrants, amongst whom the number of cases was very high. ${ }^{14}$

The natives of the region, carriers of chronic infections, were a constant source of contamination from Anopheles. Much as Robert Koch had seen in Africa, Neiva encountered infected children whose only pathological manifestation of the disease was a dilated spleen. ${ }^{15}$

There was something else that drew his attention: workers who had taken quinine regularly and had no symptoms in Xerém were struck by malaria when they visited Rio for a few days without taking the alkaloid. From September 1907 onwards, such occurrences became increasingly commonplace. So it was that in October Neiva upped the dose to $50 \mathrm{cg}$ every other day. The cases of first-time infection vanished wherever quinine administration

\footnotetext{
${ }^{10}$ Neiva, op. cit. (note 4), 133-4; Arthur Neiva, Malária e mosquitos: Coletânea II, 1906-1940 (Rio de Janeiro: Imprensa Nacional, 1941), 184.

11 Ibid., 167-94.

12 Neiva, op. cit. (note 4), 133; Neiva, op. cit. (note 10), 190-1.

${ }^{13}$ Neiva's main references at the time of the Xerém campaign were the treatises by Patrick Manson, Tropical Diseases: A Manual of the Diseases of Warm Climates (London and New York: Cassell, 1898); Botto Scheube, Die Krankheiten der warmen Länder: Ein Handbuch für Ärzte (Jena: Gustav Fischer, 1898); and Carl Mense (ed.), Handbuch der Tropenkrankheiten (Leipzig: Johan Ambrosius Barth, 1905), which were all published in several editions.

${ }^{14}$ Neiva, op. cit. (note 4), 134.

15 In studies undertaken in German colonies in Africa and New Guinea, Koch found that children who fell ill had high plasmodium levels in their blood, making them a key link in the plasmodium's life cycle. Those who survived childhood malaria acquired immunity to the disease. Koch's theory was out of step with the concept by which immunity was dependent upon the patient's race. It led to the elucidation of the role of (asymptomatic) carriers. Margaret Humphreys, Malaria, Poverty, Race and Public Health in the United States (Baltimore: John Hopkins University Press, 2001), 46-7.
} 
was strict, but the change in dosage did not halt the rise in the number of workers who fell ill when they were away from the worksite temporarily. ${ }^{16}$

In November 1907, first-time infections started to appear amongst people who had taken quinine preventively every two days. In response, Neiva started administering it every day at the same dose of $50 \mathrm{cg}$. This seemed to work, but now the disease struck those who were taking lower doses. And even amongst those who were taking the full daily dose, there were still cases of workers who would fall ill or have a relapse when they went to the capital. $^{17}$

By January 1908, the four thousand workers were receiving medication either every day or every other day, depending on where they were: 'in some locations', wrote Neiva, 'we have never, for various reasons, managed to arrange things so that we could provide safe quinine administration'. ${ }^{18}$

The only safe form of treatment was, then, '50cg taken without the exception of even a single day'. ${ }^{19}$ Even so, if treatment was interrupted for one or two days, malaria would strike. Neiva himself, upon moving away from the region and stopping taking quinine preventively, was struck with a benign tertian fever at his home in Rio de Janeiro.

In May 1908, he was dispatched to head an anti-malaria campaign in the region to be crossed by the Brazilian North-Western Railway, which stretched from the main coffee production area of São Paulo across the Mato Grosso until the border with Bolivia and Paraguay. ${ }^{20}$ It would appear that he left Xerém in January. The article he published two years later shows, from its somewhat muddled structure and imprecise data, that he had not had enough time to test experimentally the deductions he had made in the months he was working on the problem. ${ }^{21}$

Neiva wrote that he had the opportunity to observe a great number of people and thus a large quantity of human material in conditions that virtually corresponded to those of laboratory research. Two population groups offered a 'perfect contrast': the workers, who took quinine, and the women, children and other migrants - almost as numerous as the workers - who took no quinine and were 'totally attacked by malaria' ${ }^{22}$ It is likely that part of this second contingent took poor quality medications, including ones based on quinine. Meanwhile, there were differences amongst the workers because of the different dosages and frequencies with which they took the drug, depending on where they were based, and also because some workers had relapses, showing the group to be less homogeneous than it was first believed because there were infected people in its midst.

Neiva's interpretation of the situation was that the malaria haematozoon had developed resistance to quinine. But his article contains some inconsistencies on this point. In one part it says that when exposed to the constant action of quinine over a more or less lengthy period of time, the parasite became 'habituated' to it. ${ }^{23}$ Then he goes on to speculate whether the Anopheles had created an 'adaptation opportunity' for the haematozoa as they fed on blood with different degrees of 'chemical richness'. Resistance was the result of

${ }^{16}$ Neiva, op. cit. (note 4), 134-6.

17 Ibid., 138.

18 Ibid., 137.

${ }^{19}$ Ibid., 138, italics in the original.

${ }^{20}$ For more on Neiva's campaign during the building of the railway in north-western Brazil, see Benchimol and Silva, op. cit. (note 5), 737-41.

21 Neiva, op. cit. (note 4).

22 Neiva, ibid., 135.

${ }^{23}$ Ibid., 135-6. 
the haematozoa's adaptation to organic media containing different quinine levels, 'which ultimately made them resistant, so that, over the generations, they acquired the capacity to be differentiated clearly in quinine-resistant races'. ${ }^{24}$ In a third explanatory hypothesis, Neiva highlights the relationship between non-infected individuals and victims of relapses in a situation of homogeneous chemical richness, supposing that the haematozoa got accustomed to the alkaloid when they encountered it in high concentrations throughout the whole man-mosquito-man cycle. The resistant plasmodium races were formed by their cultivation in a quinine-rich environment, both in man and in vectors:

As such, growing from gametes accustomed to living in media where quinine was always present, the haematozoa in another cycle, from ookinete to the final feeding that released the sporozoite in the bloodstream, already continued to develop even in the presence of quinine. ${ }^{25}$

While this may not have been the first time such a phenomenon had been observed by tropical medicine, it seems to have been the first theory in the scientific literature on malaria to explain it. From his experience in Xerém, Neiva concluded that 'constant quinine administration amongst malarial population groups, when it is not administered equally to all the inhabitants, will give the haematozoa the means to acquire specific resistance to the point of splitting into different races'. ${ }^{26}$ In other words, he believed resistance to be a phenomenon which, from a clinical perspective, was manifested in the failure of quinine to cure patients, but whose origin lay in the development of parasite strains resistant to the drug.

The publication of Neiva's theory is related to Oswaldo Cruz's trip to the Amazon on the service of the Madeira-Mamore railway, or the 'devil's railway', as it became known for the many thousands of people who lost their lives to the disease during its construction. There, the director of the Instituto de Manguinhos noted that huge doses of quinine, up to $3 \mathrm{~g}$ a day, still failed to prevent malaria from breaking out amongst people working on the railway. ${ }^{27}$

Oswaldo Cruz reached the region where the tracks were being laid in July 1910, after the first section of the railway had been opened. In September, he delivered a report to the company containing an analysis of the sanitary conditions and his recommendations for their improvement. Notwithstanding the range of diseases that plagued the workers, the main culprit for crippling the Madeira-Mamoré works was malaria. It was so prevalent that it inverted the ratio between normal and pathological: the people, wrote Oswaldo Cruz, 'have no idea what a healthy state is' ${ }^{28}$ Morbidity was high, but mortality was far lower. The most widespread form of malaria was the most serious: aestival-autumnal, or tropical (70\%), caused by Plasmodium falciparum.

As in the campaigns run by Chagas and Neiva, emphasis was put on using quinine and providing protection against mosquito bites. Oswaldo Cruz considered the doses used in Xerém and Minas Gerais to be ineffectual in such circumstances, and proposed the daily administration of $2-3 \mathrm{~g}$, even though he noted that a daily dose of over 0.75 or $1 \mathrm{~g}$ produced signs of toxicity. ${ }^{29}$

\footnotetext{
24 Ibid., $136-7$.

25 Ibid., 137.

26 Ibid., 140.

27 Oswaldo Cruz, 'Madeira-Mamoré Railway Company: Considerações gerais sobre as condições sanitárias do Rio Madeira', in Oswaldo Cruz (ed.), Oswaldo Gonçalves Cruz Opera Omnia (Rio de Janeiro: Imprensa Brasileira, 1972), 565-624; 611.

${ }^{28}$ Ibid., 607.

${ }^{29}$ Ibid., 612-3.
} 
In his report to the company building the railway, Oswaldo Cruz endorsed Neiva's theory about the formation of quinine-resistant races of the plasmodium. Some patients continued to contain parasites in their blood $24 \mathrm{~h}$ after an intravenous dose of $6 \mathrm{~g}$ of the alkaloid! Despite noting this, he did not make any progress in his theoretical formulations about this biological phenomenon, which would go on to intrigue German researchers with broad experience in malaria prevention and treatment.

German researchers followed closely the scientific theories and innovations produced on the other side of the Atlantic. The intense commercial and diplomatic relations between Germany and Brazil, and the increasing flow of German emigrants to a country long ruled by a monarchy linked to the Habsburgs created favourable conditions for scientific interchange. ${ }^{30}$ The Archiv für Schiffs- und Tropen-Hygiene [Naval and Tropical Hygiene Archive] frequently commented on or summarised articles published by Brazilians in local or foreign journals. Many Brazilians completed their medical education in German universities or institutes. One of the progeny of German science was Adolpho Lutz, an important actor in the institute of microbiology and medical zoology in Brazil. ${ }^{31}$ And Oswaldo Cruz himself, when studying medicine in the 1880s, belonged to a group of 'Germanists' who would meet up to learn the language in order to keep up with the latest medical breakthroughs published in German journals.

The successful campaign against yellow fever led by Oswaldo Cruz in Rio de Janeiro attracted two researchers from Hamburg's Institute for Maritime and Tropical Diseases in 1904. Their mission was to observe the methods used to fight the disease and to study as yet obscure aspects of its aetiology and epidemiology. In the Brazilian capital, Hans Moritz Otto and Rudolf Otto Neumann kept in close contact with the Manguinhos Institute's staff. The expedition was sponsored by shipping companies that connected Hamburg and South America and coffee exporters like Theodor Wille: the Hanseatic port was one of the main destinations for Brazil's most important export. Later, Otto and Neumann would apply the methods used in the Brazilian capital to control yellow fever in Togoland, then a German protectorate in West Africa. ${ }^{32}$

Henrique da Rocha Lima, a founding staff member at the Instituto de Manguinhos and Oswaldo Cruz's right-hand man, had specialised in microbiology and pathology in Berlin from 1901 to 1903, and in Munich from 1906 to 1908. In 1909 he was hired by the Hamburg institute and from then until his death in 1956, Rocha Lima worked actively as a

\footnotetext{
${ }^{30}$ On the political and commercial relations between Brazil and Germany see Gerhard Brunn, Deutschland und Brasilien, 1889-1914 (Cologne: Bohlau, 1971). Tensions derived from the World War are analysed by Frederich C. Luebke, Germans in Brazil: A Comparative History of Cultural Conflict during World War I (Baton Rouge, LA and London: Louisiana State University Press, 1987). For the Weimar Republic period, there is an ambitious study encompassing all Latin America: Stefan Rinke, 'Der letzte freie Kontinent': Deutsche Lateinamerikapolitik im Zeichen transnationaler Beziehungen, 1918-1933 (Stuttgart: Heinz, 1996).

31 'A synthetic analysis of Adolpho Lutz's trajectory can be found in Jaime Larry Benchimol, 'Adolpho Lutz: Um esboço biográfico", História, Ciências, Saúde - Manguinhos, 10, 1 (2003), 13-83. With Magali Romero Sá, Benchimol coordinated the publication of Lutz's complete works, each volume containing comprehensive historical presentations in Portuguese and English.

${ }^{32}$ Hans Moritz Otto and Rudolf Otto Neumann, 'Bericht über die Reise nach Brasilien zum Studium des Gelbfiebers vom 10. Februar bis 4.Juli 1904', Archiv für Schiffs- und Tropen- Hygiene, 8 (1904), 529-51 and H.M. Otto and R.O. Neumann, Studien über das Gelbfieber in Brasilien während der auf Veranlassung des Institutes für Schiffs- und Tropenkrankheiten in Hamburg im Sommer 1904 ausgeführten Gelbfieberexpedition (Leipzig: Von Veit, 1906). A historical analysis of this expedition can be found in Felix Brahm, 'Wissenschaftsförderung der Hamburger Wirtschaft und "Wissenstransfer aus Brasilien: die Gelbfieberexpedition des Hamburger Tropeninstituts 1904"' in Sven Tode and Frank Hatje, Hamburger Wirtschafts-Chronik (Hamburg: Verlag Hanseatischer Merkur, 2003), 81-104.
} 
mediator of German-Brazilian scientific relations. ${ }^{33}$ During his stay in Munich, he helped organise Brazil's exhibits at the exhibition appended to the 14th International Congress of Hygiene and Demography held in Berlin in 1907. The Brazilian delegation presented materials illustrating the campaign against yellow fever, histopathology collections related to tropical diseases and other innovations, such as the technology used to produce bubonic plague serum and a description of the 'exoerythrocytic cycle' of the protozoan Haemoproteus columbae, an important breakthrough in malaria studies made by Henrique Aragão. ${ }^{34}$ These contributions earned Brazil a gold medal, awarded by the German empress, and awakened the curiosity of more German scientists about the research being done there.

Henrique Aragão and Alcides Godoy, another researcher at the Instituto Oswaldo Cruz, both did postgraduate studies in Germany in 1907. The following year, the Brazilian institution received two researchers from the Hamburg institute, the protozoologist Stanislas von Prowazek and the chemist Gustav Giemsa. In their six-month stay, they did research and trained young scientists at the Instituto Oswaldo Cruz. In 1910, Max Hartmann, then on the staff of Berlin's Institute for Infectious Diseases, also spent some months there. Two years later, Hermann Duerck helped to consolidate the anatomical pathology department at the Instituto Oswaldo Cruz. ${ }^{35}$

The period in which Prowazek and Giemsa were working at the Instituto Oswaldo Cruz coincided with Neiva's malaria studies and his campaigns in inland Brazil. Neiva and Prowazek even undertook a joint expedition to the Tietê river in the state of São Paulo to study its flora and fauna and also the epidemiology of malaria in the region. ${ }^{36}$ During Prowazek and Giemsa's sojourn at the Instituto Oswaldo Cruz, the institution was also visited by Ernst Rodenwaldt, an army physician also connected to Hamburg's Institute for Maritime and Tropical Diseases. He was journeying along the coast of South America as a ship's doctor on a vessel owned by the Hamburg-Südamerikanischen Dampfschifffahrtsgesellschaft [Hamburg-South America Steamship Company] ${ }^{37}$ It is therefore more than likely that Giemsa, Prowazek and Rodenwaldt learnt of Neiva's observations of quinine resistance in Rio de Janeiro's swampy lowlands before he systematised and published his findings in the first volume of Memórias do Instituto Oswaldo Cruz.

The fact that this and other articles were published in both German and Portuguese in the institute's journal shows not only Germany's leading position at the time in biomedical research, but also the close dialogue maintained by German and Brazilian specialists. It was interrupted during the First World War but was soon re-established, along with an exchange of merchandise and capital and an influx of German migrants to Brazil. ${ }^{38}$

The point we want to stress is that Brazil's involvement in the production of knowledge on tropical diseases was more complex than is suggested in traditional representations of

\footnotetext{
33 André Felipe Cândido da Silva, 'A trajetória científica de Henrique da Rocha Lima e as relações BrasilAlemanha, 1901-1956' (unpublished PhD thesis, Casa de Oswaldo Cruz/ FIOCRUZ, Rio de Janeiro, 2011).

${ }^{34}$ Magali Romero Sá, 'Studies of avian malaria and Brazil in the international scientific context (1907-1945)', História, Ciências, Saúde - Manguinhos, 18, 2 (2011), 499-518.

35 Benchimol, 1990, op. cit. (note 6), 34-7.

${ }^{36}$ An incomplete copy of Prowazek and Neiva's expedition report can be found in the Bernhard Nocht Institut für Tropenmedizin (Historical archive Bernhard Nocht Institut für Tropenmedizin, Akte 2-8, Reiseberichte, Kongresse, Stanislas von Prowazek: Zur Mündung des Tieté, undated).

${ }^{37}$ Ernst Rodenwaldt, Ein Tropenarzt erzählt sein Leben (Stuttgart: Ferdinand Enke, 1957), 53-8.

38 On Brazilian-German relations during the war, see Luebke, op. cit. (note 30).
} 
its role in international capitalism as a mere exporter of primary goods and destination of capital and manufactured products from Europe and North America.

Scientific relations between Brazil and Germany in the field of tropical medicine were very dynamic, with knowledge and innovations being produced on both sides. Not beholden to an imperial power, Brazil had developed a strong tradition in medical research that focused on local diseases that threatened both the imperial and the republican elites' nation-building and modernisation projects. This tradition created the institutional and cultural basis for its reception of cultural and scientific initiatives from the empire of Wilhelm II, including those from its chemical and pharmaceutical industry.

\section{German Medical Doctors Prove Malaria Resistance}

In Hamburg, the director of the Institute for Maritime and Tropical Diseases, Bernhard Nocht, and the head of the institute's clinical department, Heinrich Werner, would have the chance to observe resistance amongst the German workers who had been repatriated to that Hanseatic city, as mentioned before. In an article also published in 1910, they stated that they had been prepared for some quinine resistance in the malaria contracted in inland Brazil, but they had been taken aback by its strength. ${ }^{39}$

The reason Nocht and Werner were so surprised at the failure of quinine in patients from the Madeira-Mamore region was simply that the treatment they had used until then had been successful. Since the founding of the Hamburg institute and the sailors' hospital, the disease that had been most studied and treated there had been malaria. ${ }^{40}$ Nocht had developed a new method for administering quinine that differed from the method suggested by Koch, which consisted of administering $1 \mathrm{~g}$ of the drug on the ninth and tenth day of the disease. Inspired by the Italian method of fractionated dosage, Nocht was in favour of administering a total of $1 \mathrm{~g}$ every day in five separate doses for eight days running, after which time he would increase the gap between the doses (for instance, the same five doses a day for just two days) until the patient was cured. ${ }^{41}$ This method had proved successful until the influx of workers from the Madeira region of Brazil.

According to the tropical medicine specialist Ernst Rodenwaldt, amongst the specialists with experience of working in the tropics or on board ship, the way to treat malaria was 'taken for granted by all' ${ }^{42}$ The success of their methods had been proven by the constant improvement in morbidity and mortality rates amongst Europeans in the colonies. 'Several colleagues', wrote Rodenwaldt in 1919, 'will still remember the time when a malaria diagnosis in the tropics or at home would somehow lift our spirits about the patient, for we were certain we could help and promise a definite cure'. ${ }^{43}$

Amongst the workers being repatriated from the Amazon, outbreaks of fever were exacerbated by symptoms of diarrhoea, dysentery and repeated relapses. In 90 cases observed by Nocht and Werner (a number that included the patients and their relapses), 56 had tertian fever, 15 had tropical fever and 19 had mixed infections. None of the patients presented quartan fever. Unlike previous experience, the tropical form was more likely to relapse than the tertian forms, which normally was caused by a species of plasmodium that

\footnotetext{
${ }^{39}$ Nocht and Werner, op. cit. (note 2), 1558-9.

${ }^{40}$ Mannweiler op. cit. (note 3), 30.

${ }^{41}$ Nocht and Werner, op. cit. (note 2), 1557; Bernhard Nocht, 'Die Therapie der Malaria', Deutsche Medizinische Wochenschrift. 24, 12 (1909), 513-17.

${ }^{42}$ Ernst Rodenwaldt, Zur Frage der Chininresistenz der Plasmodien der menschlichen Malaria: Habilitationschrift zur Erlangung der Venia Legendi an der Ruprecht-Karls-Universität zu Heidelberg (Leipzig: Johann Ambrosius Barth, 1919), 556.

${ }^{43}$ Ibid., 556-7.
} 
tended to produce more obstinate relapses. As they observed these anomalies, Nocht and Werner progressively raised the dose of quinine they administered twofold and even more. The initial dose rose to $2 \mathrm{~g}$ and, in the complementary treatment phase, between pauses of increasing length, they would administer quinine for two or three days so that the first pause would last two days, the second three, the next four and so on until eight days' break was reached. However, the higher dose did nothing to improve the results: neither the frequency nor the seriousness of the relapses diminished. ${ }^{44}$

This 'quite unusual' circumstance led them to experiment with other products. Compounds containing arsenic had been tested by Patrick Manson in 1902 and by Peter Mühlens a year later. Koch observed the effect atoxyl had on the malaria parasite, but as it also affected eyesight, its use in treating the disease was not pursued. ${ }^{45}$ The usefulness of another compound, methylene blue, had first been reported in 1891 by Paul Ehrlich and Paul Guttmann, and had been recommended afterwards for children. ${ }^{46}$ Miguel Couto also recommended it for Brazilian malaria, which encouraged Neiva to test it in Xerém. He did find it to have some effect against the plasmodium, but its action was very slow. ${ }^{47}$ Nocht and Werner's tests using methylene blue proved similarly unsatisfactory. They nonetheless judged as 'incontestable' the effect of Ehrlich-Hata preparation 606 (Salvarsan) in five cases of quinine-resistant malaria. ${ }^{48}$ Werner tested the preparation again on Brazilian malaria, but it failed to prevent relapses in any case. ${ }^{49}$

Werner also sought to demonstrate how the Amazonian variant of the disease differed from other regions in the world. With Nocht, he had observed several clinical peculiarities, especially the more frequent disturbance of the intestine. In no patients were dysentery amoebas or bacilli encountered. They also found it notable that the nervous system was affected in two serious cases, both with symptoms of beriberi. And the spleen, while only slightly dilated in several very serious cases of malaria, was found to be 'strongly' swollen in less severe cases. Alterations of the lungs were also a characteristic of patients from Brazil: fourteen had more or less serious cases of bronchitis, which disappeared as the malaria treatment progressed. ${ }^{50}$

The doctors from Hamburg also reported temperature variations that had not previously been seen. In six cases, shortly after the fever had been abated by quinine, the patients' temperature had risen to $39^{\circ} \mathrm{C}$ for several days without any parasites being detected in the peripheral blood. Urine tests showed that there was no relationship with haemoglobinuria. They proposed that this phenomenon be known as a 'pseudo-relapse'. ${ }^{51}$

Faced with these singularities, Nocht and Werner started to wonder whether the species of parasites involved in Brazilian malaria were different, not just in their virulence and resistance, but also morphologically. The parasites in the tertian form were observed to be slightly different to the ones found in other parts of the world.

\footnotetext{
44 Nocht and Werner (note 2), 1565-6.

${ }^{45}$ Heinrich Werner, 'Über die Behandlung der Malaria mit Ehrlich-Hata-606 und über Chininresistenz bei Malaria', Archiv für Schiffs- und Tropen- Hygiene, 15 (1911), 141-56, here 141-2.

${ }^{46}$ Paul Ehrlich and Paul Guttmann, 'Über die Wirkung von Methylenblau bei Malaria', Berliner Klinische Wochenschrift, 28 (1891), 953-6.

${ }^{47}$ Neiva, op. cit. (note 10), 172-4.

48 Nocht and Werner, op. cit. (note 2), 1562-3.

${ }^{49}$ Heinrich Werner, 'Über einige Besonderheiten der Malaria aus Brasilien und über die Behandlung dieser Malaria mit Ehrlich Hata-606', Deutsche Medizinische Wochenschrift, 34 (1910), 378-81; Werner, 1911, op. cit. (note 36); Heinrich Werner, 'Weitere Beobachtungen über die Wirkung von Salvarsan bei Malaria', Archiv für Schiffs- und Tropen-Hygiene, 16, Beiheft 1 (1912), 18-36.

${ }^{50}$ Nocht and Werner, op. cit. (note 2), 1563-4.

51 Ibid., 1569.
} 
In an article published in 1910, the Tropeninstitut researchers did not put forward any explanation for the development of quinine resistance. Only the following year did Werner discuss it theoretically, differentiating two forms of resistance: that acquired during the passage of the plasmodium through warm-blooded animals - that is human hosts - and that acquired in the passage through insects. The first form, resulting from the repeated effect of quinine on the plasmodium, was correlated to the prolonged use of the alkaloid in malaria treatment. This would partially explain the resistance seen in the cases from the Amazon, including the Peruvian Amazon, where quinine had been used to fight malaria for centuries. ${ }^{52}$ Meanwhile, Werner thought it unlikely that the second form - during the passage through the insect - existed. For Neiva, the high levels of quinine absorbed by the insects as they fed on human blood were enough to assure the continued or even increased resistance of the parasites in their passage through the vector. According to Werner, research by Gustav Giemsa and Heinrich Schaumann had demonstrated that the level of alkaloid in human blood was too low for a new generation of resistant parasites to develop from the fertilisation of the insect. ${ }^{53}$ The Hamburg researcher believed it was impossible to reach any firm conclusions about the phenomenon of resistance based on deductions that were 'primarily theoretical'. 54

The tests made by Nocht and Werner with methylene blue and Salvarsan show that they were attuned with the chemotherapy developed by Paul Ehrlich and his collaborators. The resistance of trypanosomes to atoxyl studied by Ehrlich from 1907 onwards influenced in large measure the analysis of the phenomenon now observed with malaria parasites. According to Christoph Gradmann, Ehrlich was interested in the trypanosomes' resistance to atoxyl not so much for its clinical importance as for the fact that it could furnish evidence about the existence of cell receptors and to support his theory about the drug's action on the cell, which he compared with the relationship between toxins and antitoxins. Ehrlich conceived resistance as an 'inheritable trait of the parasite', writes Gradmann. ${ }^{55}$

Both Bernhard Nocht and Ernst Rodenwaldt wrote that the results obtained in experiments with protozoan parasites of the blood like trypanosomes could not be extrapolated to intracellular parasites. According to Nocht (1919), the trypanosomes' resistance to drugs was stable, and was maintained after many passages, while quinine resistance disappeared in plasmodia after prolonged interruption of medication in the same host. Rodenwaldt was not so sure of this, but added that the disappearance of alterations in the malaria plasmodia was in part due to the fact that their asexual reproduction was more complex than that of trypanosomes.

New theories emerged during the First World War, where the havoc wreaked by malaria in the Balkans, Turkey and Syria made resistance to quinine a top priority.

\section{Malaria During the First World War: Quinine Resistance on the German Medical and Scientific Agenda}

'The action of quinine often left much to be desired, both therapeutically and prophylactically,' wrote the army physician Wilhelm Hoffmann as he weighed up the

\footnotetext{
52 Werner, op. cit. (note 36), 153-4.

53 Ibid., 155.

${ }^{54}$ Werner, op. cit. (note 36), 156.

55 Christoph Gradmann, 'Exploring the therapeutic biology of the parasite: "antibiotic resistance and experimental pharmacology 1900-1940"' in Ana Romero et al. (eds), Circulation of Antibiotics: Journeys of Drug Standards, 1930-1970 (Madrid: Consejo Superior de Investigaciones Cientificas, 2010), 5-22.
} 
impact of malaria on German troops. ${ }^{56}$ The initial optimism after the discovery of its aetiology and transmission and the success of experiments to control the disease in specific geographical contexts was badly shaken during the First World War, forcing the specialists in the field to review the epidemiological and scientific studies on the disease. ${ }^{57}$ In Macedonia in particular, British, French and German troops were struck by particularly devastating epidemics and caught off-guard by the inefficacy of the classic preventive and therapeutic methods. The infection rate amongst the local people was $60-95 \%$ and the very high density of mosquitoes made it impossible to control the vector. In late 1916, French army doctors were alarmed to find that sixty thousand men had lost their lives to malaria in the region, half of the French military contingent. The British troops faced a similar fate. ${ }^{58}$

Malaria starts to appear as a serious sanitation issue in German medical records in early 1916. ${ }^{59}$ Let us turn to the testimony of Ernst Rodenwaldt: 'first of all, prevention seemed to fail, then the cure. Everything indicated that quinine was not the specific medication one had hoped for, or was being administered incorrectly, or that there must be interferences that reduced or prevented its expected efficacy'. ${ }^{6}$

Some doctors even defended the idea that in regions like Macedonia, Albania or the Taurus mountains there was a different form of malaria that could not be treated with quinine. Its prophylactic use, considered by the doctors working in the tropics to be essential, started to be seen with increasing scepticism by the doctors working on the front. They argued that it fostered a certain resistance and worsened the chances of treatment with the alkaloid when infection hit. ${ }^{61}$ The drug's side effects - queasiness, weakness, bleeding under the skin, impaired sight and hearing, chest pain and blackwater fever - made it hard to get the soldiers to stick to the treatment. For this reason, Peter Mühlens, head of the clinical section at the Tropeninstitut, recommended, as Neiva had in the Baixada Fluminense lowlands in Brazil, strict supervision by the sanitation officials to

\footnotetext{
56 Wilhelm Hoffmann, Los médicos alemanes en la Guerra Mundial: Su actuación y experiencia (Madrid: Calpe, 1922), 195.

57 Bernardino Fantini, 'Malaria and the First World War' in Wolfgang U. Eckart and Christoph Gradmann, Die Medizin und der Erste Weltkrieg (Pfaffenweiler: Centaurus, 1996), 241-72, here 241-2. For more about British troops, see Mark Harrison, 'Medicine and the Culture of Command: The Case of Malaria Control in the British Army During the two World Wars', Medical History, 40, 4 (1996), 437-52; C.H. Treadgold, 'The Prophylactic Use of Quinine in Malaria: With Special Reference to Experiences in Macedonia', British Medical Journal, 2993, 1 (May 1918), 525-9 and W.G. Willoughby and L. Cassidy, Antimalarial Work in Macedonia among British Troops (London: L.K. Lewis, 1918). For more on the French position, see Pierre Abrami, 'Le paludisme primaire en Macédoine et son traitement', La Presse Médicale, 17 (22 mars 1917), 161-4 and J. Bouygues, 'Le paludisme macédonien', La Presse Médicale, 13 (mai 1918), 244-6.

${ }^{58}$ Fantini, op. cit. (note 57), 247; 250-1 and J.A. Nájera, 'Malaria Control: Achievements, Problems and Strategies', Parassitologia, 43, 1-2 (2001), 1-89.

${ }^{59}$ Mannweiler, op. cit. (note 3), 66.

${ }^{60}$ Rodenwaldt, op. cit. (note 42), 557.

61 'Although no declared position against prophylaxis was taken in German and Austrian medical publications ... as it was a military order, its repudiation may often be noted between the lines', wrote Rodenwaldt (Ibid., 568). The British openly questioned the preventive use of quinine, putting greater faith in mechanical forms of protection (mosquito nets) and eliminating breeding grounds. But this measure could not be employed on a large scale (Fantini, op. cit. (note 57), 247-8). In 1918, for instance, C.H. Treadgold maintained that the prophylactic use of quinine was a 'fraud perpetuated from generation to generation, simply because public opinion has never been duly enlightened so as to address the problem scientifically': see C.H. Treadgold, 'The Prophylactic use of Quinine in Malaria with Special Reference to Experiences in Macedonia', British Medical Journal, May 11 (1918), 525-9, cited in Fantini op. cit. (note 57), 263.
} 
make sure they actually ingested the quinine. The servicemen would often hide the drug and later exchange it for cigarettes or alcohol. ${ }^{62}$

Certain authors suggested that many supposed cases of (biological) quinine resistance were not just down to human resistance and the inadequate use of the drug, but also to the general state of the patients, who suffered from malnutrition, stress and fatigue because of the physical and emotional impact of the war. ${ }^{63}$

At the time of the war, few German doctors were familiar with the clinical aspects of malaria and how to treat and prevent it, because, according to Rodenwaldt, 'having been eliminated from Germany half a century ago, except for small enclaves, malaria was no more than a curiosity in medical teaching before the war' ${ }^{64}$ This explains why so many of them were so little prepared for dealing with it during the conflict. ${ }^{65}$ To make matters worse, it seems that the military sanitation organisation failed to give clear, standard guidelines on how to fight the disease. ${ }^{66}$ Nevertheless, the new circumstances provided an unprecedented opportunity for verifying findings from previous, more sporadic observations of malaria on a far larger scale, albeit with little control over the conditions. Ultimately, the war served as a 'great experimental field for malaria research and especially for evaluating the prophylactic and therapeutic efficacy of quinine' ${ }^{67}$

Whenever quinine was taken preventively, the doses used varied greatly. In some regions around $1 \mathrm{~g}$ quinine was administered a day, while in others the troops would receive $1.8 \mathrm{~g}$ in ten days. For Rodenwaldt, prevention with less than $2 \mathrm{~g}$ of quinine a week was ineffectual. ${ }^{68}$ Treatment had to be continued for two to three weeks after the malariainfested region was left, warned Mühlens, but this rarely took place. There were also disagreements over the best way of using quinine: whether in tablets, in a solution, or in subcutaneous or intramuscular injections. ${ }^{69}$

Apart from the hypothesis that there was a specific form of the disease in the Balkans and Turkey, other theories were also put forward to account for the failure of treatment or prevention using quinine. In a bid to make some sense of the arguments and opinions that abounded, Martin Mayer distinguished two forms of resistance: Chininabstümpfung - 'dulling or insensitivity to quinine' - due to factors within the patient's body that made the individual unresponsive to the alkaloid - and Chiningewöhnung - 'adaptation

\footnotetext{
62 Peter Mühlens, 'Über die Malariabekämpfung', in Jahrbuch 1927 des katholischen Vereins für missionsärztliche Fürsorge und des missionsärztlichen Instituts (Aachen: Aachener Missionsdruckerei Akt.Gesellschaft, 1927), 11-18.

63 Alfred Plehn, a highly regarded doctor specialising in tropical medicine at the time, believed the hypothesis that the plasmodium could adapt to quinine in certain kinds of mosquito to be valid, but in 1918 he attributed resistance 'to the unfavourable somatic and psychic conditions of our troops in the Orient and of those "cultural pioneers" who make inroads into new malaria-ridden tropical regions'. Albert Plehn, 'Ein chininresistenter Tropikastamm', Archiv für Schiffs- und Tropenkrankheiten, 22, 2 (1918), 201-11.

64 Rodenwaldt, op. cit. (note 42), 555. A similar statement can be found in Mühlens: 'For decades, Germany has been free from endemic and epidemic malaria, except in a few zones, like the north-west, the Oder and the Vistula estuaries or the neighbourhood of Leipzig': Peter Mühlens, 'Über Malariagefahren und ihre Verhütung durch Chininprophylaxe und Chininbehandlung', Münchener Medizinische Wochenschrift, 63, 39 (1916), 1398-9.

65 Rodenwaldt, op. cit. (note 42), 555; Bernhard Nocht, 'Über die Therapie der Malaria', Wiener Medizinische Wochenschrift, 69, 9 (1919), 429-38; Erich Martini, 'Die biologische Malariabekämpfung in Mazedonien', Zeitschrift für angewandte Entomologie, 7, 2 (1921), 225-86.

${ }^{66}$ Nocht, op. cit. (note 65).

${ }^{67}$ Fantini, op. cit. (note 57), 242.

68 Rodenwaldt, op. cit. (note 42), 561.

${ }^{69}$ Peter Mühlens, op. cit. (note 64).
} 
to quinine' - referring to what took place inside the parasite. ${ }^{70}$ In the former case, physiological processes were responsible for the drug's diminished effectiveness, witnessed by the reduced excretion of quinine in the urine or its reduced concentration in the blood. Gustav Giemsa and Joseph Halberkann, from the Hamburg institute, questioned these results: the excretion of quinine did not prove that it had failed to exert any action against the parasite in the organism. However, the products of the alkaloid's decomposition could be involved in the process, and this was something Giemsa turned his attention to. ${ }^{71}$

Nocht felt that the inefficacy of ever larger doses of quinine was not related to the emergence of strains of quinine-resistant parasites, as Neiva had suggested. Rather, he attributed the diminished or non-existent effect of quinine to the weakening of the organism's defences and the prolonged and inappropriate use of the drug. ${ }^{72}$

The fact is that the parasite's or human organism's resistance to quinine involved complex issues that were beyond the grasp of medical science at the time. Indeed, several aspects of the epidemiology and physiopathology of malaria would remain obscure. 'Resistance to quinine' became a polysemic concept, employed in different circumstances depending on the author's principles or procedures. If before the war Neiva and Werner spoke of a property developed in the parasites, during the war the phenomenon started to be related to the inefficacy of the alkaloid caused by incorrect prophylaxis, organic factors like immunity, the social resistance of troops ascribable to the drug's side effects, and so on. In an attempt to avoid the ambiguity suggested by the word 'resistance', Martin Mayer, from the Hamburg institute, proposed a distinction between insensitivity to quinine, referring to the patient's organism, and quinine adaptation, a characteristic developed by the parasite.

It was not clear how quinine acted on the parasite. The hypothesis of direct action was refuted by laboratory evidence that the concentration of the alkaloid in the blood was far lower than that needed to kill the microbe. ${ }^{73}$

One theory, called 'repulsion theory', proposed by Julius Morgenroth in 1917, was that quinine would build up inside erythrocytes and would there repel the parasites by chemostatic action, preventing them from penetrating the cell. Free in the blood stream, their life cycle was interrupted and they were destroyed. However, if they were only repelled by erythrocytes, argued Rodenwaldt, it was hard to imagine how these plasmodia would adapt to a drug that had no direct effect on them. ${ }^{74}$

Morgenroth viewed the action of quinine in the light of the principle of selective action proposed by Ehrlich, with whom he had worked. ${ }^{75}$

When it came to the life cycle of the plasmodium, the process by which it resisted immune reactions and the effects of quinine, remaining quiescent in the organism until the disease relapsed, was still a mystery. It was not known where in the body it remained, nor whether it was capable of being maintained inside other cells than erythrocytes. The

\footnotetext{
${ }^{70}$ Cited in Rodenwaldt, op. cit. (note 42), 564-5.

${ }^{71}$ Gustav Giemsa and Joseph Halberkann, 'Über das Verhalten des Chinins im menschlichen Organismus', Archiv für Schiffs- und Tropen-Hygiene, 21 (1917), 20-1; 333-49; Rodenwaldt, op. cit. (note 42), 564-7.

72 Nocht, op. cit. (note 65), 431.

73 Rodenwaldt, op. cit. (note 42), 573-5.

74 Ibid., 578-9.

75 From 1897 Julius Morgenroth was one of Ehrlich's assistants in the Steglitz Institute for Serum Research and Serum Testing, near Berlin. In 1899, they moved to the Institute of Experimental Therapy in Frankfurt, where Morgenroth worked until 1905. From 1906 to 1919, he was director of the Department of Bacteriology of the Institute of Pathology at the Charite Hospital in Berlin, and from 1919 to 1924, the year of his death, Morgenroth headed the Department of Chemotherapy at the Robert Koch Institute. With Ehrlich, Morgenroth published a series of works on haemolysins and for this he is recognised as one of the founders of chemotherapy.
} 
'asymptomatic carriers of parasites' and the chronically ill were held accountable for the introduction of the disease to areas prone to epidemics. For this reason, military doctors started to 'incite' the manifestation of hidden infections, using techniques that included submitting individuals suspected of being infected to temperature shocks or physical exertion followed by hot and cold baths. ${ }^{76}$

In a chapter on malaria in the respected Handbuch der Tropenkrankheiten [Handbook on Tropical Diseases] by Carl Mense, published between 1917 and 1918, Hans Ziemann distinguished three forms of resistance by the plasmodium to quinine. The first was due to the parasites being lodged in capillaries of internal organs. The second, to the existence of quinine-resistant 'races' in certain regions like Brazil, which could have existed previously or have developed in response to the overuse of the drug. ${ }^{77}$ Finally, the third form was indirect resistance via the failure of the patients' defences. Ziemann had summarised the different explanations, but had made no progress in developing a theory, thereby corroborating Nocht and Mühlens' statements that the abundant literature on malaria published after the war discussed specific problems concerning the epidemiology, physiopathology, treatment and prevention of the disease, but failed to put forward any satisfactory solution for most of the enigmas the doctors on the front line had been faced with. $^{78}$

Neiva and Werner's theoretical speculations continued to be the most comprehensive attempts to explain quinine resistance, even if they were riddled with inaccuracies and gaps. However, the idea that the parasite acquired resistance to the alkaloid during its life cycle in humans and/or in mosquitoes, and that it was able to transmit resistance to its offspring, was refuted by Ernst Rodenwaldt, who in 1919 wrote one of the most robust works on the subject, presented as a thesis to the University of Heidelberg. ${ }^{79}$ 'Why have

\footnotetext{
${ }^{76}$ Hoffmann, op. cit. (note 46), 193. In an article published in 1919, Martin Mayer states that the inducement of the manifestation of latent malaria infections was a 'well known practice of tropical doctors'. The patients were subjected not only to cold and warm baths and to physical exertions like horseback or bicycle riding, but also to X-ray exposure and other methods. Martin Mayer, 'Ergebnisse und Probleme der Malariaforschung im Krieg', Deutsche Medizinische Wochenschrift, 45, 3 (1919), 59-62. Peter Mühlens also refers to these practices used for diagnosing chronic infections. Besides cold douches aimed at the spleen region and X-ray radiation, he mentions adrenalin or strychnine injections and administrations of small doses of quinine. Peter Mühlens, 'Malaria' in George Klemperer and Felix Klemperer (eds), Neue Deutsche Klinik, (Berlin and Vienna: Urban Schwarzenberg, 1930), Bd. VII, Lehrgang 31, 122-49, here 129.

${ }^{77}$ Hans Ziemann, 'Die Malaria' in Carl Mense (ed.), Handbuch der Tropenkrankheiten, Vol. 5 (Leipzig: Johann Ambrosius Barth, 1924), 356-60.

78 Nocht, op. cit. (note 65) and Peter Mühlens, 'Die Methoden der Malariabekämpfung', Sonderabdruck aus Knolls Mitteilungen für Ärzte, Heft 3 (1926) - Collection of articles in the historical archives of the BernhardNocht Institut für Tropenmedizin.

${ }^{79}$ Rodenwaldt, op. cit. (note 42). On Rodenwaldt's career, see: H. J. Jusatz, 'Ernst Rodenwaldt (08.05.1878-06.04.1965)', Zeitschrift für Tropenmedizin und Parasitologie, 16, 3 (October 1965), 233-34; H.J. Jusatz, 'Ernst Rodenwaldt (1878-1965) als Begründer der geo-medizinischen Forschung', Heidelberger Jahrbucher, 14 (1970), 23-51; Wolfgang U. Eckart, 'Generalarzt Ernst Rodenwaldt' in Gerd Rolf Ueberschär (ed.), Hitlers militärische Elite: Von den Anfängen des Regimes bis Kriegsbeginn, Bd. 1, (Darmstadt: Primus Verlag, 1998), 210-22 and Manuela Kiminus, 'Ernst Rodenwaldt, Leben und Werk' (unpublished PhD thesis: University of Heidelberg, 2002). Part of his scientific work and career are described in Mannweiler op. cit. (note 3), 131-2 and Friedrich Hansen, 1907-2007: Deutsche Tropenmedizinische Gesellschaft - Eine Chronik (Hamburg: Deutsche Gesellschaft für Tropenmedizin und Internationale Gesundheit e.V., 2007). The dispute with Mühlens over the directorship of the Institute of Tropical Diseases in Hamburg and over the leadership of tropical medicine in Germany is analysed by Wulf op. cit. (note 3), 129-40. Rodenwaldt worked there between 1907 and 1910. In 1908 he travelled to South America as a ship's doctor with the Hamburg-Süd shipping line. He spent a month in Brazil and visited the Instituto Oswaldo Cruz, where Giemsa and Prowazek were working as visiting researchers. Ernst Rodenwaldt, op. cit. (note 37), 53-8.
} 
our skills failed in the Balkans and Turkey if before the war tropical medicine had so many successful experiences?' he wondered. ${ }^{80}$ Let us, then, examine the ideas he galvanised to explain the complex biological process by which the malaria parasites became resistant to quinine.

\section{Ernst Rodenwalt and Quinine Resistance in the Light of Modern Genetics}

Writing in his memoirs about the German retreat from Asia Minor, where he had worked as a hygiene adviser, Rodenwaldt relates that he took advantage of the six-week wait for a passage to Europe to study Wilhelm Johannsen and Erwin Baur's theories of heredity. ${ }^{81}$ Upon reaching Germany, he decided to enrol at the Medicine Department of Heidelberg University, where he wrote a thesis about the question that had intrigued him since he had been in Africa: the resistance of the malaria plasmodium to quinine. ${ }^{82}$ In his memoirs he adds that in his thesis he took pains to apply the notions of genetics to the issue of infection, being at the time a 'staunch believer' in August Weissmann's theories of heredity. ${ }^{83}$

A defender of Darwin's theories and critic of the inheritance of acquired characteristics, an idea associated with Lamarck but admitted by Darwin himself, Weissmann, a German biologist, proposed the almost absolute constancy and autonomy of what was known as the 'germinative plasma', an element responsible for carrying the hereditary factors in a way that was completely immune to the influence of the 'sum', the rest of the body, which merely transmitted the germinative plasma from one generation to the next. The 'germinative plasma' would only change under exceptional circumstances, so that any alteration the organism went through during its life would not be transmitted by hereditary means. ${ }^{84}$ Weissmann thus ruled out any environmental influence on genetic inheritance. The blending of Weissmann and Mendel's conceptions in the early years of the twentieth century meant that heredity was seen as a 'fixed condition that was inherent to the biological characteristics of individuals'. ${ }^{85}$

But Rodenwaldt's formulations about quinine resistance were more strongly influenced by Wilhelm Johannsen and Erwin Baur, whose insights contributed towards a reworking of Gregor Mendel's ideas from the early 1900s onwards, especially concerning the emergence of species. Different theories were expounded to explain the mechanisms by which different variants - and therefore new species - emerged, as well as the processes involved in transmitting these variations through successive generations. ${ }^{86}$ The discussions were polarised: the 'Mendelians' or 'Mutationists', who rejected the role of natural selection as a mechanism of evolution, holding that only mutations responsible for major modifications could have some role in the emergence of new species; and

\footnotetext{
${ }^{80}$ Rodenwaldt, op. cit. (note 42), 574.

${ }^{81}$ Rodenwaldt op. cit. (note 37), 195; 199.

${ }^{82}$ Ibid., 198-9. After spending some time at the Hamburg Institute for Tropical Diseases, Rodenwaldt went to Togo (then a German colony) as a doctor with the Colonial Service, staying there from 1910 until the end of 1913.

83 Ibid., 199.

${ }^{84}$ Roberto de Andrade Martins, 'August Weismann, Charles Brown-Séquard e a controvérsia sobre herança de caracteres adquiridos no final do século XIX', Filosofia e História da Biologia, 5 , 1 (2010), 141-76, here 147.

${ }^{85}$ Vanderlei Sebastião de Souza, 'A política biológica como projeto: A "Eugenia Negativa" e a construção da nacionalidade na trajetória de Renato Kehl, 1917-1932' (unpublished Master's thesis: Casa de Oswaldo Cruz/Fiocruz, Rio de Janeiro, 2006), note 116. Also see Nancy Stepan, The Hour of Eugenics: Race, Gender and Nation in Latin America (Ithaca, NY and London: Cornell University Press, 1991).

${ }^{86}$ For an overview of this discussion, see Ernst Mayr, O desenvolvimento do pensamento biológico: Diversidade, evolução e herança (Brasília: Universidade de Brasília, 1998).
} 
the 'Biometricians', like Karl Pearson, who not only recognised natural selection as the principal driving force for evolution, but also the idea that small, continuous variations led to the development of new species. ${ }^{87}$ In the midst of this debate came the experiments by a Dane, Wilhelm Johannsen, on pure lines of beans, showing that natural selection was only induced by genetic differences, not environmental ones. Johannsen distinguished the genotype, or the set of factors responsible for heredity, from the phenotype, which were the observable characteristics of individuals. While phenotypes varied continuously, genotypes varied discontinuously. As such, he conciliated the views of the Mendelians and the Biometricians. Individuals with pure lineages - that is, with the same genetic material, resulting from self-fertilisation - could have different phenotypes in response to different environmental conditions, but their genotype would remain the same. ${ }^{88}$

Erwin Baur followed a similar path with his fertilisation and hybridisation experiments on plants. He concluded that an organism's appearance was the result of the influence of Mendelian traits and also a response to its environment. Mendelian factors only determined the breadth of an organism's reactions to its environment. Like Johannsen, Baur distinguished environmentally-induced changes from heredity. He conceded that mutations could modify genetic traits, but not on the scale proposed by the 'mutationists'. They took place on a small scale, resulting in such subtle changes that they often went unnoticed. These small mutations were important in the formation of new races, but not of new species. ${ }^{89}$ In Einführung in die experimentellen Vererbungslehre [Introduction to the Experimental Doctrines of Inheritance], a book published in 1914 and re-edited in 1919, Baur mentions the resistance of the plasmodium to quinine. He did not see this property as being an inheritance of acquired modifications:

In this case, as in others, it is naturally far more reasonable to concede that isolated races of malaria parasites had differing resistances to quinine, and that by treating an infected person with the drug, a more resistant race that already existed was simply cultivated in the pure form..$^{90}$

In a similar vein and also drawing on Weissmann, Johannsen and Baur's ideas, Rodenwaldt sought to refute Neiva and Werner's Lamarck-inspired interpretation. They both held that the parasite developed resistance to quinine over several generations, maintaining or increasing its resistant features in its passage through mosquitoes. For Neiva, the quinine the mosquito absorbed when it fed on blood was in some way implicated in the process, although this is an idea that Werner ruled out as he thought that the quantity of alkaloid in the blood was too small for this.

For Rodenwaldt, none of these hypotheses explained the failure of quinine in Brazil, the Balkans or Turkey, nor the contrast with successful cases of tropical medicine in the colonies. ${ }^{91}$ Neither did they explain the failure of the prophylaxis, nor the way the

\footnotetext{
${ }^{87}$ For more on the debate between the Mendelians and the Biometricians, see Robert Olby, 'The Dimensions of Scientific Controversy: The Biometric-Mendelian Debate', British Journal for the History of Science, 22 (1989), 299-320.

${ }^{88}$ Staffan Müller-Wille, 'Leaving inheritance behind: Wilhelm Johannsen and the politics of Mendelism' in Max Planck Institut für Wissenschaftsgeschichte, A Cultural History of Heredity IV: Heredity in the Century of the Gene (Berlin: Max Planck Gesellschaft, 2008), 7-18; Lourdes Aparecida Della Justina et al., 'A herança genotípica proposta por Wilhelm Johannsen', Filosofia e História da Biologia, 5, 1 (2010), 55-71.

${ }^{89}$ Alexander von Schwerin, 'Seeing, breeding and the organisation of variation: Erwin Baur and the culture of mutations in the 1920s' in Max Planck Institut für Wissenschaftsgeschichte, op. cit., 259-78; Jonathan Harwood, Styles of Scientific Thought: The German Genetics Community 1900-1933 (Chicago: Chicago University Press, 1993), 229-73.

${ }^{90}$ Erwin Baur, Einführung in die experimentellen Vererbungslehre (Berlin: Gebrüder Borntraeger, 1919), 41.

${ }^{91}$ Rodenwaldt, op. cit. (note 42), 587.
} 
preparations were used, nor the circumstances of war, nor factors relating to the human organism, nor even the existence of a specific form of malaria in the combat zones. So what could explain the phenomenon observed there and in Brazil?

Rodenwaldt believed that plasmodium strains that had different levels of susceptibility to quinine, but the same physical features, emerged spontaneously in nature. Most of the parasites quickly succumbed to the action of the alkaloid, while a few races were selected. 'It is not a matter of the creation or cultivation of quinine-resistant strains, as most authors would have us believe, but pre-existing quinine-resistant strains that are selected'. ${ }^{92}$ Selection took place when quinine was used in too small quantities in regions where malaria was widespread and where the arrival of non-immune people provoked more virulent forms of the disease. This process could take place in regions where quinine had been used for centuries, such as the South American mountain ranges, or over a short period of time where a large population group was submitted to the same pattern of administration of the drug. The incomplete prevention or cure of patients contributed to the development of chronic malaria, as in the regions where growing resistance to quinine had been observed.

This dependence of the selection of quinine-resistant races on the greater or lesser efficacy of therapeutic treatments explained why the problem did not occur in regions like Germany, where malaria had been endemic for a long time, or Italy, which had had a systematic process for fighting the disease for some time:

The main consequence of treatment in a country with doctors and where the people are used to the therapy until the disease is eradicated was that the selection of quinine-resistant races was prevented, because the use of high doses of quinine until the parasites were killed made it impossible for epidemic levels to be reached. ${ }^{93}$

In the tropics, selection did not take place because the native population had a degree of immunity to the disease and almost never took quinine, while Europeans were generally treated correctly. There, the rare relapses and quinine resistance occurred only in people who had the bad luck of being infected with an already existing strain that had not passed through selection. ${ }^{94}$

But although there were signs that the plasmodia from regions where there was quinine resistance presented morphological particularities, this was not essential for proving that there were different races of the parasite, Rodenwaldt argued. His acceptance of Johannsen's views is evident in the distinction he makes between genotype and phenotype to interpret the phenomenon of resistance. Alterations to the phenotype did not in any way alter the genotype, whose constitution remained constant. Therefore, the alterations could not be transmitted by hereditary means:

In a morphologically identical population of plasmodia, but with a different genotypical behaviour towards quinine, it is possible that quinine-resistant races can be isolated by selection; that is, plasmodia that have the same phenotypical appearance, but which behave differently towards quinine, could lead to the selection of a quinine-resistant race with common phenotypical and genotypical features. ${ }^{95}$

If Rodenwaldt owed Johannsen the distinction between variations in visible characteristics and variations in hereditary material, the core of his theory was based on Baur's deductions. The 'environment' that selected quinine-resistant strains was

\footnotetext{
92 Ibid., 589.

93 Ibid., 591.

94 Ibid., 594.

95 Ibid., 598
} 
understood in a broad sense as being an ecological and social environment. In the Balkans and Turkey, the environment was war-ravaged, crossed by people who were physically and psychically weakened, where troops came into contact with villages rife with chronic malaria and other diseases, and where army doctors had little familiarity with treating malaria, a key ingredient in view of the importance Rodenwaldt gave to the correct administration of preventive and therapeutic quinine in his theory. He recognised that his ideas could not yet be proven experimentally. Similar experiments to Johannsen's would have to be done on pure lines of plasmodia, that is ones with homogeneous genotypes.

In 1919, in the Archiv für Schiffs- und Tropen-Hygiene, Rodenwaldt published an article about the plasmodium's resistance to quinine. ${ }^{96}$ The following year, Werner Rosenthal (1920), from Göttingen, author of Tierische Immunität [Animal Immunity], praised the Heidelberg professor for his contribution, but criticised how he had presented the concepts of immunity and resistance in malaria. ${ }^{97}$ Rodenwaldt's response leads us to a new ramification of the debates and investigations about this disease that experience in the war had made such a moot scientific and epidemiological issue, here approaching it not from the perspective of genetics, but immunology, a field of knowledge that went on to gain ground in experimental and practical medicine. ${ }^{98}$ The material researched for this paper is not yet enough to analyse these discussions about the problem of quinine-resistant malaria in any great depth. Basically, Rosenthal accused Rodenwaldt of mistaking a non-specific form of immunity observed in people from a region with chronic malaria with the specific elements of the defence mechanisms activated by the organism in its interaction with the pathogen. Europeans were prone to malaria in the tropics because they did not have this non-specific resistance and because they were weakened by the unfamiliar climatic conditions. Rodenwaldt argued back that this 'resistance' was no more than a form of nonabsolute immunity. Unlike immunity in bacterial infections, he went on, malaria immunity was developed very slowly through continued exposure to the parasite, that is in the chronic form of the disease. He further stated that it did not produce long-lasting effects, as seen in bacterial diseases, and could be dissipated by internal or external factors (other illnesses, physical debilitation, etc.). Even so, when individuals with this kind of immunity, which he called 'unstable', were exposed to a new infection, they tended to exhibit far milder symptoms which would subside more readily under drug-based therapy. ${ }^{99}$

Rodenwaldt was involved in another far less gentlemanly exchange of views with another former student of the 'Hamburg school', Viktor Schilling, who visited Brazil in 1912. ${ }^{100}$ As a physician and hygiene adviser in Turkey and Syria, Schilling had observed several cases of malaria that showed resistance to mounting doses of quinine. ${ }^{101}$ It appears that as early as 1917 he had written a communiqué about this subject which was not published because of strict censorship at the time. ${ }^{102}$ His comments only became public two years later in the Archiv für Schiffs- und Tropen-Hygiene and Deutsche Medizinische

\footnotetext{
${ }^{96}$ Ernst Rodenwaldt, 'Zur Frage der Chininresistenz der Plasmodien der menschlichen Malaria', Archiv für Schiffs- und Tropen-Hygiene, 23 (1919b), 23-4; 555-99.

${ }^{97}$ Werner Rosenthal, 'Bemerkungen zu dem Aufsatz von Ernst Rodenwaldt: Zur Frage der Chininresistenz der Plasmodien', Archiv für Schiffs- und Tropen-Hygiene, 24, 6 (1920), 142-4.

98 Ernst Rodenwaldt, 'Zu obigen Bemerkungen Werner Rosenthals, Göttingen', Archiv für Schiffs- und TropenHygiene, 24, 6 (1920), 145-6.

99 Ibid.

${ }^{100}$ For further information about Viktor Schilling, see Mannweiler op. cit. (note 3), 199-200.

101 Some 30 Turkish leper colonies were under Schilling's responsibility with around ten thousand patients (ibid., 67-8).

102 Viktor Schilling, 'Zur Frage der Chininresistenz', Archiv für Schiffs- und Tropen-Hygiene, 27, 4 (1923), $115-8$, here 117.
} 
Wochenschrift, at the same time that Rodenwaldt was publishing his thesis. ${ }^{103}$ According to Schilling:

The conditions that Neiva, Nocht, Werner, Mühlens and others have presented as being propitious for the development of quinine-resistant races are valid. The parasites have always found a way to partially escape quinine, increase their virulence in new ground and adapt in some way to the alkaloid ... generally speaking, I am less inclined to accept that the parasites develop hereditary resistance to quinine, and deem it more likely that that there is selection and increased virulence in particularly virulent, resistant strains. ${ }^{104}$

Later, in 1921, Schilling modified his view slightly, bringing it more into line with Rodenwaldt's:

I have reached the idea of parasite races that are resistant to quinine by practical means, in a severely affected population which received an unreliable supply of the alkaloid, [with the process observed not being due] to developed and inherited resistance, but rather to selection and increased virulence, especially in more lethal and resistant parasite strains. Rodenwaldt later tried to make selection the theoretical basis for this process, exactly in the same sense I gave to him. ${ }^{105}$

Rodenwaldt reacted to this claim, which he believed diminished his contribution to the debate, thus: 'It is far easier, with so many and such broad possibilities, for the person to defend the idea as their own later, when one of these lines becomes more likely.' He went on to reiterate his belief in the selection of pure lineages of already existing resistant strains 'in which, furthermore, nothing is altered, there is no increase or diminishment of virulence, and they do not adapt to anything at all' ${ }^{106}$

In his rebuttal, Schilling accused Rodenwaldt of having appropriated his ideas, which he had learnt about in Smyrna, a province in south-western Turkey, where they had met in 1918. ${ }^{107}$ Even so, Schilling acknowledged that the way Rodenwaldt had developed Baur's ideas was 'an interesting, independent theoretical accomplishment which far outstrips my scant experiences derived from practice'. ${ }^{108}$

Rodenwaldt's reply $(1923 b, 404)$ was curt and was accompanied by a note by the Archiv editors: the tone of the text had been moderated, as it had involved accusations of a personal nature, and the 'objective discussion' of the matter was now closed. ${ }^{109}$

\section{Concluding Remarks}

Today, the resistance of the plasmodium to antimalarial drugs is one of the big problems facing international health care, prompting the continued development of different therapeutic compounds and combinations of drugs. ${ }^{110}$ In this study, we show that quinine resistance was already recorded in the early decades of the twentieth century in some

103 Viktor Schilling, 'Über die schwere zilizische Malaria', Archiv für Schiffs- und Tropen-Hygiene, Pathologie und Therapie exotischer Krankheiten, 23 (1919), 487-98; Viktor Schilling, 'Über relativ chininresistente Malaria im cilicischen Taurus und Amamus', Deutsche Medizinische Wochenschrift, 45, 17 (1919) , 463-4.

104 Quoted in Schilling, op. cit. (note 102), 115.

105 Viktor Schilling, 'Kriegshygienische Erfahrungen in der Türkei', Archiv für Schiffs- und Tropen-Hygiene, 25, Beiheft 3 (1921), 5-41. We did not have access to this paper, for which reason the quote is taken from Ernst Rodenwaldt, 'Zur Frage der Chininresistenz - Eine Bemerkung zu V. Schilling, Kriegshygienische Erfahrungen in der Türkei', Archiv für Schiffs- und Tropen-Hygiene, 27, 4 (1923), 113-5, here 8.

106 Rodenwaldt op. cit. (note 105), 113-5. It is strange that Rodenwaldt's reaction only came two years after Schilling's article was published. We have not been able to identify the reason for this.

107 Schilling, op. cit. (note 102), 115.

108 Schilling, op. cit. (note 102), 117.

109 Rodenwaldt, op. cit. (note 105), 404.

${ }^{110}$ Ivone Manzali de Sá, 'A resistência à cloroquina e a busca de antimalariais entre as décadas de 1960 e 1980', História, ciências, saúde-Manguinhos, 18, 2 (2011), 407-30. 
regions of Brazil, giving rise to different theories to explain it. At the time, the alkaloid was practically the only option available for preventing and treating outbreaks of malaria.

The theory of the development of quinine-resistant races of the plasmodium put forward by Arthur Neiva would appear to be the first scientific work in the literature about malaria that attempted to give an explanation for the persistence of the disease even when the alkaloid was taken in ever higher doses. These preliminary hypotheses were never verified theoretically or experimentally by Neiva, the researcher from the Oswaldo Cruz Institute, whose career took a different turn. Meanwhile in Brazil, the supremacy of preventive approaches which focused primarily on the vector of malaria (adopted in the campaigns started by the Rockefeller Foundation after the First World War) put strategies designed to address the parasite, and the preventive and therapeutic use of quinine on the back burner. Neiva's hypothesis does not seem to have inspired any particular interest amongst Brazilian specialists. ${ }^{111}$

Neiva's observations about the malaria parasite's resistance to quinine reveal the interdependency between laboratory and field work in overcoming public health problems and producing new knowledge about tropical diseases. It is no wonder he called Xerém a 'vast field of observations and experiments'. ${ }^{112}$ This interdependency is characteristic of the institutionalisation of experimental medicine during the Brazilian Belle Époque. The anti-malaria campaigns were a key part of the collaborative efforts of doctors keen to make their names as scientists in conjunction with the public and private 'clients' that sought their assistance, through both the old and the new biological and medical institutions in which they worked. They did research, ran projects and ultimately made important advances in the most pressing problems of the day, affecting not just public health, but also engineering, farming and resource exploitation. ${ }^{113}$

Field research was essential for understanding what linked human population groups to parasites, with their complex life cycles and multiple vectors, in intricate chains of interdependency in the natural and social ecosystems. In a manner that was not unlike the scientists working for the administrations of European colonial possessions, Brazilian researchers like Neiva saw the unexplored Brazilian hinterland as a potential repository of new scientific data. As Helen Tilley reports about Britain's African colonies, 'while they [the colonial scientists] evoked the authority of laboratory knowledge, they simultaneously challenged the physical boundaries and natural validity on which that authority was based'. ${ }^{114}$ The wetlands in the Fluminense lowlands were not exactly a laboratory because they presented the biological phenomena in all their complexity in a space that was partially immune to the manipulations and controls inherent in

\footnotetext{
111 This can be seen in a speech given by Carlos Chagas at São Bento in 1933: 'it was in this campaign [in Xerém] that Dr Arthur Neiva verified, in a great number of cases, the appearance of acute manifestations of malaria when, outside the centres [of infection] the use of quinine was suspended. That researcher interpreted the fact as potentially indicating the existence of quinine-resistant hematozoon races, but the more widely accepted interpretation today is different, in which quinine, not destroying the parasites, prevents their intense proliferation in the organism', Carlos Chagas, Luta contra a malária: Conferência realizada em abril de 1933 no Núcleo Colonial São Bento (Rio de Janeiro: Tip. do Departamento de Estatística e Publicidade, 1934), $20-1$.

112 Neiva, op. cit. (note 10), 172.

113 In order to lend legitimacy to the transformation of the Manguinhos Serum Therapy Institute into an experimental entity where production, research and teaching were undertaken, Oswaldo Cruz had, to a certain extent, to associate the knowledge produced there with the prevailing social and political demands (Stepan, op. cit. (note 6), 109-12; Benchimol, op. cit. (note 6).

114 Helen Tilley, Africa as a Living Laboratory: Empire, Development, and the Problem of Scientific Knowledge, 1870-1950 (Chicago and London: Chicago University Press, 2011).
} 
experimental research. The complexity of the events that unfolded there challenged the findings obtained inside laboratories. However, the field was a fine observation context for malaria because at the time the different plasmodium species related to it could not be grown artificially. According to Leo Slater, by different routes from those of Neiva and other tropical medicine specialists, researchers working on new drugs for malaria did their best to reconstitute the complex connections between parasite, host and vector in the laboratory. ${ }^{115}$

In Brazil's vast unexplored inland regions, researchers like Arthur Neiva and Carlos Chagas obtained new knowledge for tropical medicine. As had been the case when the theory of quinine resistance had been formulated, it was also in a campaign to fight malaria (in Itatinga, in 1905) that Chagas formulated his hypothesis about domestic infection by anophelines, ${ }^{116}$ which would be called on years later to support the campaign to kill malaria vectors by using DDT inside homes. While he was engaged in a campaign against malaria in the worksites for the Central do Brasil railway, Chagas identified the clinical, etiological and epidemiological phenomena of a new human trypanosomiasis which was later named after him.

Just as it had been propitious for the study of quinine resistance, the exchange between Brazil and Germany contributed to the communication of the discovery of Chagas Disease. It was in the Archiv für Schiffs- und Tropenhygiene that the Brazilian scientist first published his findings, identifying Trypanosoma cruzi, its vector, and the clinical aspects of the disease, which was so different from the well-known sleeping sickness. The recognition of the Brazilian discovery came in June 1912, when Chagas was awarded the Schaudinn Prize by the Hamburg Institute of Maritime and Tropical Diseases as the best work in the field of protozoology. Interestingly, the presence of German researchers at the Instituto Oswaldo Cruz contributed towards the theoretical research of the new trypanosomiasis, as reported by Magali Sá. ${ }^{117}$

Malaria, Chagas Disease and ancylostomiasis formed the triad of diseases which, during and after the First World War, galvanised debate in Brazil about the need to extend public health services into the inland areas of the country. This 'sanitation movement' was spearheaded by intellectuals, writers and scientists, including Chagas and Neiva, who drew attention to the prevalence of disease amongst the people who were left 'at the mercy of God when it came to medical care'. ${ }^{118}$ According to Neiva, one of the factors that exacerbated malaria amongst these population groups was the incorrect use of quinine, which was sold mainly in the form of a sulphate that was effective neither for prevention nor for treatment.

\footnotetext{
115 Leo Slater, War and Disease: Biomedical Research on Malaria in the Twentieth Century (New Brunswick, NJ and London: Rutgers University Press, 2009), 11.

116 Benchimol and da Silva, op. cit. (note 5).

${ }^{117}$ Magali Romero Sá, 'The History of Tropical Medicine in Brazil: The Discovery of Trypanosoma cruzi by Carlos Chagas and the German School of Protozoology', Parassitologia, 47 (2005), 309-17.

118 Neiva, op. cit. (note 10), 120. For more on the sanitation movement, see Nísia Trindade Lima and Nara Britto, 'Salud y Nación: propuesta para el saneamento rural: Un estúdio de la revista Saúde, 1918-1919' in Marcos Cueto (ed.), Salud, Cultura y Sociedad en América Latina: Nuevas perspectivas históricas (Lima: Instituto de Estudos Peruanos/ OPAS, 1996). Gilberto Hochman, A era do saneamento (São Paulo: Hucitec, 1998), 135-58; Nísia Trindade Lima and Gilberto Hochman, “Pouca saúde, muita saúva”: sanitarismo, interpretações do país e ciências sociais', in Gilberto Hochman and Diego Armus (eds), Cuidar, controlar, curar: Ensaios históricos sobre saúde e doença na América Latina e Caribe (Rio de Janeiro: Fiocruz), 493-533.
} 
As head of public health in São Paulo from 1916 to 1920, Neiva faced some serious malaria epidemics in inland and coastal areas of Brazil's richest state. ${ }^{119}$ Alongside measures to attack the mosquitoes, he recommended treating the sick with quinine. The difficulty of importing it during the First World War prompted him to start quinine production at the Butantã Institute, run by the São Paulo public health service. ${ }^{120}$

From the 1920s onwards, Neiva started working mainly in the organisation and administration of scientific institutions and, from 1930, as a politician. ${ }^{121}$ Even though he no longer researched malaria, it continued to be a topic of interest to him, albeit now in the arena of debates and political action. And despite having witnessed quinine resistance first-hand, Neiva held by the opinion that it was the most reliable method for preventing and treating the disease. In a letter he wrote in 1935 to a fellow public health expert, he criticised the aggressiveness with which the German pharmaceuticals industry was marketing its new antimalarial agents:

I am sure that quinine will valiantly withstand all these tests, but responsible work must be done under strict scientific determinism, and these new products manufactured by German laboratories after experiments using bird haematozoa and launched on the market under treacherous commercial conditions must be kept at bay. ${ }^{122}$

One of the people involved in marketing the new malaria drugs was Peter Mühlens, director of the clinical section of the Institute for Tropical Diseases in Hamburg. In August 1925 he tested plasmoquine on patients at the sailors' hospital. This drug had been developed that year by Werner Schulemann, Fritz Schonhöfer and August Wingler in the laboratories of IG Farben by modifying quinoline, one of the main components of quinine. ${ }^{123}$ In 1930, IG Farben also brought out atebrine, developed by Hans Mauss and Fritz Mietzsch. ${ }^{124}$ These synthetic malarial agents were presented as being more effective and incurring fewer side effects than quinine. Mühlens deployed his network of scientific and political contacts to get testing approved in Balkan nations like Romania and Bulgaria, and also in Latin America, especially in 1931, when he was in Venezuela, Guatemala and Mexico. ${ }^{125} \mathrm{He}$ was also in Mexico in late 1926, when he faced some resistance to the promotion of the new malaria drugs being supported by the German foreign ministry as part of its cultural diplomacy efforts. The Mexican press warned Mühlens that the public references to plasmoquine compromised his medical standing. A Mexican military doctor also censured him for behaving not as a scientist, but as a 'sly travelling marketeer'. ${ }^{126}$

\footnotetext{
${ }^{119}$ For more on these malaria eradication campaigns in inland São Paulo, see Francisco Salles Gomes Jr, Prophylaxia do Impaludismo em Vila Americana, Nova Odessa, Carióba e Salto Grande, Coleção Serviço Sanitário de São Paulo, 9 (São Paulo: Weizflog Irmãos, 1919).

120 On this topic, see Jaime Larry Benchimol and Luiz Antônio Teixeira, Cobras, lagartos e outros bichos: Uma história comparada dos institutos Oswaldo Cruz e Butantan (Rio de Janeiro: Ed. UFRJ/ Fiocruz/ Casa de Oswaldo Cruz, 1993), 118-21.

${ }^{121}$ For more on Arthur Neiva's career, see Thomas Borgmeier, 'Arthur Neiva: A propósito de seu $60^{\circ}$ aniversário', Revista de Entomologia, 11, 1 e 2 (1940), 1-104.

122 Carta de Arthur Neiva a Octavio Gonzaga de 07.05.1935. Arquivo Arthur Neiva, CPDOc - FGV, RJ. Notação: ANc 1916.11.27.

123 According to Slater (op. cit. (note 115), 60), two of the motives for the development of synthetic malarial agents in Germany were the difficulty of procuring quinine during the First World War and the lack of any colonies where Cinchona could be grown. For more on the development of plasmoquine by Bayer, see HorstBernd Dünschede, Tropenmedizinische Forschung bei Bayer (Dusseldorf: Michael Triltsch, 1971), 55-82.

124 On this subject, see ibid. 55-82; Slater, op. cit. (note 115), 69-70.

125 Wulf, op. cit. (note 3), 56; Dünschede, op. cit. (note 123), 77.

126 Cited in Ludger Weß, 'Menschenversuche und Seuchenpolitik: Zwei unbekannte Kapitel aus der Geschichte der deutschen Tropenmedizin', 1999, Zeitschrift für Sozialgeschichte des 20. und 21. Jahrhunderts, 8 (1993),
} 
In a series of articles published not just in German, but also in English, Spanish, French and Italian, Mühlens set forth the advantages of plasmoquine and atebrine over quinine. The resistance of the plasmodium to the alkaloid was cited as one of its main disadvantages. Mühlens also enumerated the main side effects of quinine as being blurred vision, nausea and ringing of the ears, and associated it with blackwater fever and 'quinine idiosyncrasy'. ${ }^{127}$ In a text written with Bernhard Nocht, Mühlens did admit that the malaria parasite may come to develop resistance to plasmoquine 'analogous to the socalled "quinine-resistance", but went on to say that the veracity of this hypothesis "remains for the present a debatable point'. ${ }^{128}$ A publication from the following year shows that he saw resistance differently from Neiva and Rodenwaldt, which suggests that the latters' hypotheses had not left the theoretical realm:

My personal views on the matter have always been that the apparent 'resistance to medicine' was less a characteristic of the parasite itself or even of certain strains of parasites than of the infected individual, in whom it represented a lowering of the protective powers of the organism. ${ }^{129}$

In a chapter on malaria in the renowned clinical medicine handbook edited by Klemperer, Mühlens again stressed this aspect. He claimed that many cases of 'tropical malaria' (caused by $P$. falciparum) were found to be resistant to treatment using drugs because the treatment was 'inadequate': 'this is why during the war and in the following years so much was said about the malaria parasites' resistance to quinine.' But this resistance was down to weakened immunity caused by factors such as malnutrition or other diseases. 'Without doubt, the strength of the organism's defences exerts a fundamental role in any therapy. The medication alone is not capable of leading to a cure.' This was equally true for quinine and plasmoquine, whose action on the plasmodium was indirect. ${ }^{130}$

When the National Socialist Party came to power in 1933, Mühlens competed for the top position at the Institute of Tropical Medicine in Hamburg. However, he was up against another key figure in this narrative, Ernst Rodenwaldt, the Nazi Party's favourite for his staunch anti-Semitism and his involvement in the study and communication of theories of racial hygiene. ${ }^{131}$ From 1921 to 1934 , when he was working in Dutch colonies in South East Asia, primarily combating malaria, Rodenwaldt published dozens of papers about racial hygiene or eugenics. His involvement with the problem of quinine resistance certainly influenced the campaign strategies adopted in Asia.

This attempt to apply modern heredity theories to the study of an infectious disease could be seen as a milestone in the development of ideas that ultimately led to his being well known as a 'racial hygienist'. According to Heiner Fangerau, the combination of

10-50, here 21. For more on Mühlens's time in Mexico in 1926, see Felix Brahm, 'Die LateinamerikaBeziehungen des Hamburger Tropeninstituts, 1900-1945' (unpublished Master's thesis, University of Hamburg, 2002), 67-73.

127 See, for example, Peter Mühlens, 'Über Plasmochin-Erfahrungen: Vortrag gehalten auf der Tagung der Deutschen Tropenmedizinischen Gesellschaft, Tübingen 12-14 September', Archiv für Schiffs- und TropenHygiene, 33, Beiheft 3 (1929), 44-50; Peter Mühlens, 'Die synthetischen Malariamittel Plasmochin und Atebrin', Münchener Medizinische Wochenschrift, 79, 14 (1932), 537-46; Mühlens, 'La lucha contra el paludismo con los nuevos medicamentos sintéticos Plasmoquina y Atebrina', Revista Médica Germano-Ibero-Americana, 5, 4 (1932b), 169-78.

128 Bernhard Nocht and Peter Mühlens, 'The treatment of malaria with Plasmoquine' (unpublished text - Arquivo Histórico do Bernhard Nocht Institut für Tropenmedizin, collection of articles).

${ }^{129}$ Peter Mühlens, 'Modern Methods of the Treatment and Prophylaxis of Malaria by Medicaments', Chinese Medical Journal, XLVII (1933), 1401-10.

${ }^{130}$ Peter Mühlens, op. cit. (note 76), 138; 142.

${ }^{131}$ Wulf, op. cit. (note 3), 84. 
Mendel and Weissmann's ideas that formed the groundwork for Rodenwaldt's analyses of resistance represented 'a watershed for the theories of racial hygiene, it becoming clear how predictable was the inheritance of isolated features'. ${ }^{132}$ Rodenwaldt's trajectory took a similar turn to one of his mentor's, Erwin Baur, the ideologue behind eugenics and author, with Eugen Fischer and Fritz Lenz, of the manual that inspired Hitler's racial conceptions set forth in Mein Kampf (Fangerau, 2000). Die Mestizen auf Kisar (1927), about the hereditary transmission of the biological features of a mixed-race population, earned Rodenwaldt an eminent position in the International League of Racial Hygiene. During the years of National Socialism, he was the main link between tropical medicine and the much-touted racial conceptions of the day. In the words of Wolfgang Eckart, Rodenwaldt was a 'notable protagonist of anthropology and racial hygiene in Germany in the 30s and 40s', fervently defending racial segregation. ${ }^{133}$

As shown by Christoph Gradmann with regard to trypanosomes and arsenic compounds, the analysis of quinine resistance on the part of the plasmodium shows that this became an object of investigation far before the phenomenon gained the full attention of the medical community because of bacterial resistance to antibiotics starting in the 1960s. But unlike Gradmann's findings concerning trypanosomes, the plasmodium's resistance to quinine was closely related to the frequency with which it occurred as a clinical phenomenon. ${ }^{134}$

Years after the debates about the resistance of the malaria plasmodium to quinine, the resistance of bacteria to antibiotics prompted equally heated discussions in the field of genetics. Angela Creager ${ }^{135}$ suggests that the researchers involved in bacterial genetics in the 1940s and 50s rejected the conceptions of Lamarck, by which microbes 'adapted' to drugs and transmitted this property to their progeny. However, the bacteriologists had the chance to replicate resistance in the laboratory as they cultivated bacteria in the presence of antibiotics, unlike the researchers working on malaria resistance at the beginning of the century. The role of mutations in the emergence of variations that granted bacteria their resistance was discussed. From the perspective of Mendelian genetics and Darwinism, resistance was seen as the selection of mutated lineages that had developed randomly from a population of bacteria that were sensitive to the antibiotic. Experimental studies and theoretical speculations, Creager continues, led to the identification of the means by which the genetic inheritance was transmitted without involving the chromosome core, ultimately revealing that "in the end, "adaptation" versus "mutation" turned out to be a false dichotomy'. 136

The interpretations of bacterial resistance to antibiotics were applied to the analysis of the similar phenomenon seen amongst malaria parasites: spontaneous mutations conferring reduced sensitivity to a given drug or class of drugs. ${ }^{137}$ Nevertheless, from the 1950s onwards, the drug that drew specialists' attention when it came to resistance

\footnotetext{
${ }^{132}$ Heiner Fangerau, 'Das Standardwerk zur menschlichen Erblichkeitslehre und Rassenhygiene von Erwin Baur, Eugen Fischer und Fritz Lenz im Spiegel der zeitgenössischen Rezensionsliteratur 1921-1941' (unpublished PhD thesis: University of Bochum, 2000), 14.

133 Wolfgang Eckart, Medizin und Kolonialimperialismus, Deutschland 1884-1945 (Paderborn, Munich, Vienna and Zurich: Ferdinand Schöning, 1998), 521.

134 Gradmann, op. cit. (note 55).

135 Angela N.H. Creager, 'Adaptation or Selection? Old Issues and New Stakes in the Postwar Debates over Bacterial Drug Resistance', Studies in History and Philosophy of Biological and Biomedical Sciences, 38 (2007), 159-90.

136 Creager, op. cit. (note 135).

137 Peter B. Bloland, Drug Resistance in Malaria (Atlanta: World Health Organization and CDC, 2001); Harald Noedl et al., 'Malaria Drug-Sensitivity Testing: New Assays, New Perspectives', Trends in Parasitology, 19, 4
} 
was not quinine, but chloroquine, the most widely used drug in malaria treatment since its development. ${ }^{138}$ Its proven efficacy considerably restricted the use of quinine, and chloroquine was itself succeeded by other drugs, including primaquine, mefloquine and proguanil. This fact helps explain why Neiva, Nocht, Werner and Rodenwaldt's observations had such a limited impact and became reduced to mere footnotes in narratives about malaria treatment. ${ }^{139}$ And yet, echoes of these authors' deductions can be heard in the way researchers currently address the plasmodium's resistance to chloroquine and other drugs: population movements induce the introduction of resistant parasite strains, while the widespread, large-scale use of the drugs operates as a 'selective pressure' in that it removes populations of susceptible protozoa and maintains the resistant ones. ${ }^{140}$ The ways the leading actors and conceptions in malariology interacted in different contexts in the twentieth century are not clear-cut and beg further exploratory study. The scientific and geopolitical cartography that emerged after the Second World War was a far cry from the context when Neiva, Nocht and Rodenwaldt were active in their fields. This war fostered appropriations of scientific ideas and actions that are not always clear or obvious. The alliance between German researchers and the German chemicals and pharmaceuticals industry, which was strengthened during the Weimar Republic, became tarnished during the Nazi regime and the Second World War. Not only was Rodenwaldt an active promoter of racial hygiene theories, for which he was put on trial at Nuremberg, but, when the Germans retreated in the face of the advancing Allied troops, he was also instrumental in the destruction of Italy's sanitation engineering system, which had ensured the control of malaria in the country, resulting in a significant upsurge in the proliferation of the disease.

It is also important to remember that the potentialities and limitations of the work of Neiva and other Brazilian scientists were also related to the fact that it was produced in a country which by many was considered subaltern to Europe's 'centres of civilisation'. However, as we follow the research and disputes on both sides of the Atlantic, we can see not just how internationalised tropical medicine was in those early decades of the twentieth century, but also how the interaction between the researchers on both sides took such complex and convoluted paths and dynamics. Brazilian doctors like Arthur Neiva, Miguel Couto and Oswaldo Cruz did not restrict themselves to adopting and adapting theories and practices that circulated through publications, correspondence, conferences, exchanges of patients and biological materials, but actually formulated new concepts and theories that had an impact on the 'central' social formations.

The study of the historical records about the resistance of the malaria parasite to quinine demonstrates how important the research into the topic was to individual careers and to the formation of collective ideas, which, despite being involved in international research programmes, followed 'national styles' in the way they studied and fought the disease, a prototypical 'tropical disease', even if it was then still a threat in other latitudes.

(2003), 175; Umar Farooq and R.C. Majahan, 'Drug Resistance in Malaria', Journal of Vector-Borne Diseases, 41 (2004), 45-53.

138 For more on the development of chloroquine, see Slater, op. cit. (note 115), 80-3.

${ }^{139}$ See, for instance, W. Peters's 'Drug Resistance in Malaria - a Perspective', Transactions of the Royal Society of Tropical Medicine and Hygiene, 63, 1 (1969), 25-40; Jane Achan et. al., 'Quinine, an Old anti-Malarial Drug in a Modern World: Role in the Treatment of Malaria', Malaria Journal, 10, 1 (2011), 144-56.

${ }^{140}$ W. Peters, op. cit. (note 139); Peter Bloland, op. cit. (note 137). The similarity of Peters' explanatory model (from the Liverpool School of Tropical Medicine) to Rodenwaldt's is obvious: 'Parasital populations may adapt to the introduced chemical environment and thereby enter the state of drug resistance. They are capable of passing on their genetic information to future generations of drug-resistant malaria parasites'. 